\title{
REFLECTION NOTE: EU DATA PROTECTION RULES AND THE LACK OF COMPLIANCE IN SWEDEN
}

\author{
ESTER HERLIN-KARNELL*
}

\section{INTRODUCTION}

Imagine that your private information is available online: your house address, your date of birth, how many square meters you live on, if you rent your house, your civil status, what car you drive and what people vote in your neighborhood. The list is long. It is not voluntary Facebook. It is Sweden, and is without prior consent of the individual. Sweden claims that the General Data Protection Regulation (GDPR) is not applicable to companies if they buy a publishing license, so-called 'utgivarbevis'. ${ }^{1}$ Anyone who pays that license is exempted from the GDPR, the argument goes, because it gives them the freedom of expression and the right to publish, also supported by the Swedish transparency rules. ${ }^{2}$ Largely absent from this claimed derogation from the GDPR, however, is the question as to whether the Swedish exception breaches primary EU law on data protection (Article 16 TFEU and Article 8 EU Charter), as well whether the exception from the GDPR is proportionate. A private person or company, can pay the state to get a license without much scrutiny and it gives them a carte blanche to share information about individuals. ${ }^{3}$ In addition, these private actors who buy those licenses can earn a profit from advertisement when publishing information about individuals and in certain cases they even sell the information. ${ }^{4}$ This seems not to be about freedom of expression, but rather about conducting business. Likewise, if the argument is one of general concern for freedom of expression there is something important missing here, namely a proportionality assessment.

In this short reflection paper, I will set out to explain how and why Sweden breaches EU data protection rules. I will start by providing a brief overview of the EU data protection framework to paint the background picture. Thereafter I will discuss the scope for derogating from the obligations set out in the GDPR and thereby test the Swedish exception and show that it is not proportionate and undermines the purpose of the GDPR. Subsequently, I will discuss why some core fundamental rights of EU law should not be possible to derogate from, when as in the Swedish case it seems to boil down to economic question of who gets to own the data. I will conclude by linking the question of the right to data protection and

\footnotetext{
* Professor of EU law, University of Gothenburg. Thanks go to Anna Wallerman Ghavanini and the anonymous reviewer of this journal for very helpful comments on an earlier draft, with the usual disclaimer. ${ }^{1}$ Regulation (EU) 2016/679 of the European Parliament and of the Council of 27 April 2016 on the protection of natural persons with regard to the processing of personal data and on the free movement of such data, OJ L 119, 4.5.2016, p. 1-88 .

2 http://www.mprt.se/sv/att-sanda/internetpublicering/utgivningsbevis/

${ }^{3} \mathrm{Ibid}$, it costs 2000 Swedish $\mathrm{kr}$ for a licence.

${ }^{4}$ See eg. Mr Koll website https://mrkoll.se/. The website received a fine in 2019 by the national data protection authority for publishing credit information about individuals, but not for publishing other private information. https://www.datainspektionen.se/nyheter/2019/sanktionsavgift-pa-35-000-euro-mot-sajtenmrkoll/.
} 
why licenses should not give companies a carte blanche to publish personal data about people in Sweden to the question of market access. There is an imbalanced relationship here, to use the internal market vocabulary, with Swedish people having all their private data published online while other EU states do not do that. Likewise, there is an external dimension here: the data is available on the internet globally and therefore third countries also access it.

\section{THE DATA PROTECTION FRAMEWORK IN THE EU - SETTING THE SCENE}

What is EU data protection? In EU law, data protection is formulated as a right. Consequently, the right to data protection is codified in Article 16 TFEU and in Article 8 EU Charter. In addition, Article 7 EU Charter stipulates the right to privacy, communication and family life, and Article 8 ECHR also sets a general right to privacy, communication, home and family life. With Article 16 TFEU, Articles 7 and 8 of the EU Charter, and Article 8 ECHR stating the general right to data protection and privacy. Considering the consequences in the area of law enforcement and the use of, for example, digital evidence, it is arguable that data protection also has the status of a general principle of EU law. ${ }^{5}$ Recent case law and scholarship suggests that this is the case. ${ }^{6}$

EU data protection is a hot topic at the moment, and with a dynamic case law taking shape. In several cases the CJEU has asserted the_right to data protection, as constituting an EU fundamental right. In Digital Rights, the Court annulled the 2006 Data Retention Directive, which was aimed at fighting crime and terrorism, and which allowed data to be stored for up to two years. ${ }^{7}$ It concluded that the measure breached proportionality on the grounds that the Directive had too sweeping a generality and therefore violated, inter alia, the basic right of data protection as set out in Article 8 of the Charter. The Court pointed out that access by the competent national authorities to the retained data was not made dependent on a prior review carried out by a court or by an independent administrative body whose decision sought to limit access to the data to what was strictly necessary for the purpose of attaining the objective pursued. Nor did it lay down a specific obligation on Member States designed to establish such limits. The EU legislator had provided an insufficient justification - it was simply not good enough from the perspective of EU fundamental rights protection. The approach was confirmed in Schrems $I^{8}$ where the Court held that:

[L]egislation not providing for any possibility for an individual to pursue legal remedies in order to have access to personal data or to obtain the rectification or erasure of such data, does not respect the essence of the fundamental right to effective judicial protection, as enshrined in Article 47 of the Charter.

\footnotetext{
${ }^{5}$ See eg. the contributions in Katja Zeigler, Violeta Moreno-Lax and Päivi Neuvonen (eds), Handbook on EU General Principles, (Edward Elgar 2021) forthcoming.

${ }^{6}$ See eg. the recent Ulf Bernitz, Sylbe De Vries, Xavier Groussot, Jaan Paju (eds) General Principles of EU Law and the EU Digital Order (Kluwer law 2020).

${ }^{7}$ Case C-293/12, Digital Rights Ireland, judgment of 8 April 2014. See also the discussion in E Herlin-

Karnell, The Constitutional Structure of Europe's Area of Freedom, Security and Justice and the Right to Justification (Hart publishing 2019), ch 4.

${ }^{8}$ Case C-362/14, Data Protection Commissioner v Maximillian Schrems ECLI:EU:C:2015:650.
} 
To the list of recent cases confirming the centrality of a high standard of EU data protection is the recent Schrems II case, making it clear that data protection is a mandatory precondition for the EU entering into agreements with third states. ${ }^{9}$ In addition, the Court acknowledges that the reach of EU measures and data protection only applies to the EU territory. In the opinion of this author, it can only be hoped that comparative law, judicial and legislative, borrowing might spread this EU fundamental rights value of data protection. Opinion 1/15 is also interesting here as an affirmation of the strong focus on data protection in the Court. In this case the Court annulled a pending Agreement between Canada and the EU on the transfer and processing of Passenger Name Record (PNR) data. ${ }^{10}$ The Court held that the Agreement granted too sweeping a purpose of fighting terrorism without concrete justification in the individual case just simply a general concern of public security and without respecting private life and data protection (Articles 7 and 8 of the Charter, Article 16 TFEU) and proportionality (Article 52 of the Charter). The PNR Agreement would have permitted data retention for up to five years. ${ }^{11}$ The Court specifically stated that the Agreement needs to limit the retention of passenger name record after departure to that of passengers in respect of whom there is objective evidence from which it may be inferred that they may present a risk in terms of the fight against terrorism. ${ }^{12}$ Indeed, most of the recent cases on EU data protection cases concern the transferring of data to third countries, and the question of equivalent protection. Moreover, the proportionality test is crucial in these cases. The importance of proportionality reasoning was, of course, confirmed in the recent case of Privacy International affirming that mass surveillance without any justification or concrete suspicion presented, much in line with the Digital Rights case, mentioned above, is contrary to EU data protection as it does not stand the proportionality test. ${ }^{13}$ Similarly, in the recent La Quadrature $d u$ Net, an obligation requiring the general and indiscriminate retention of traffic and location data is incompatible with the Charter. ${ }^{14}$ In both cases the Court emphasized that legislation which permits the general and indiscriminate transmission of data to public authorities entail general access and that national legislation requiring providers of electronic communications services to disclose traffic data and location data to the security and intelligence agencies by means of general and indiscriminate transmission exceeds the limits of what is strictly necessary and cannot be considered to be justified, within a democratic society. ${ }^{15}$

Accordingly, EU data protection of a very high standard in the EU, it is simply declared to be of fundamental importance. Yet what about the enforcement of EU data protection, i.e. when an EU Member State does comply with the fundamentals of data protection in the EU territory? Much of the debate on enforcement has been constructed around the possibility of Member States derogating from EU law and the possibility of national

\footnotetext{
${ }^{9}$ Case C-311/18, Data Protection Commissioner v Maximillian Schrems (Schrems II) EU:C:2020:559.

${ }^{10}$ Opinion 1/15 EU:C:2016:656.

11 Paras 154-78.

12 Para 232.

${ }^{13}$ Case C-623/17 Privacy International v Secretary of State for Foreign and Commonwealth Affairs and Others EU:C:2020:790.

${ }^{14}$ Joined Cases C-511/18, C-512/18 and C-520/18, La Quadrature du Net EU:C:2020:791.

15 The Court refers to Article 15(1) of Directive 2002/58, read in the light of Article 4(2) TEU and Articles 7, 8 and 11 and Article 52(1) of the Charter.
} 
constitutional courts acting as a rebutter of EU law when national constitutional values are endangered which would be contrary to supremacy in classic EU law doctrine. ${ }^{16}$ In this setting the debate is focused on the value of pluralism as well as on the constitutional structure of the EU. ${ }^{17}$ There is also a well-known debate taking place currently on 'backsliding' - or regression - and the current challenges to the rule of law in certain EU Member States such as Poland and Hungary. ${ }^{18}$ The EU has a well-known enforcement problem of course. But this could be remedied by a political willingness to implement EU law correctly, especially when EU law gives the individual a more far-reaching protection than national law, such as the case of the lack of adequate data protection in Sweden.

\section{DEROGATIONS FROM THE GDPR?}

In order to verify the above stated arguments, it is needed to look a bit more closely at the exceptions provided by the GDPR. First of all, the GDPR is based on Article 16 TFEU which means that the right to data protection is the norm. The Swedish state claims that it is free to derogate from the GDPR, as in certain circumstances the GDPR allows for national divergences such as respect for constitutional provisions, security concerns as well as journalistic freedom and freedom of expression. The derogation regarding the possibility of freedom of expression is to protect the freedom of the press and journalists. But the publishing licenses under discussion here, ('utgivarbevisen') are too general and applies to very different subjects. Both traditional journals and periodicals as well as to individuals and companies, in general, are subject to the same license. ${ }^{19}$ Yet everything in connection with the licenses, do not concern press ethics and that of the freedom of journalists but about publishing information that is obtained from the Swedish authorities and then sold on or used to generate income from advertising ads. While newspapers and other media are under a strict editorial review and internal press ethics apply to them, the licenses (utgivarbevisen) are sold by the authorities to other stakeholders without much scrutiny who republish information on the internet. The state earns money from selling the licenses. How can that be freedom of expression? Regardless, the freedom to publish other persons private data must then be balanced against other rights, namely an individual's right to data protection, privacy and respect for their dignity and this balancing test is never done in Swedish practices.

Freedom of expression, safeguarded in inter alia Article 11 of the EU Charter, can be limited when democratic values are at stake. There are many examples of this in the ECHR framework. ${ }^{20}$ As the Court pointed out in the Schrems 2 case, in order to satisfy the requirement of proportionality according to which derogations from and limitations on the

\footnotetext{
${ }^{16}$ Costa v ENEL C-6/64 ECLI:EU:C:1964:66.

${ }^{17}$ For this extensive debate see eg. the discussions in Armin von Bogdandy and Jürgen Bast (eds) Principles of European Constitutional Law (Oxford/Munich, Hart/Beck, Nomos, 2009), Mattias Kumm, 'Beyond Golf Clubs and the Judicialization of Politics: Why Europe Has a Constitution Properly So Called’ (2006) 54 American Journal of Comparative Law, 505, Matej Avbejil and Jan Komarek (eds) Constitutional Pluralism in the European Union and Beyond (Hart publishing 2012).

${ }^{18}$ See Laurent Pech and Kim Lane Scheppele "Illiberalism Within: Rule of Law Backsliding in the EU" (2017), 19 Cambridge Yearbook of European Legal Studies 3-47 and see eg. Case C-619/18, Commission v Poland EU:C:2019:531.

19 https://www.prv.se/sv/utgivningsbevis/varfor-utgivningsbevis/.

20 https://www.coe.int/en/web/freedom-expression/freedom-of-expression-and-information-explanatorymemo.
} 
protection of personal data must apply only in so far as is strictly necessary, the legislation in question which entails the interference must lay down clear and precise rules governing the scope and application of the measure in question and imposing minimum safeguards, so that the persons whose data has been transferred have sufficient guarantees to protect effectively their personal data against the risk of abuse. ${ }^{21}$ The value of dignity is always at the heart of any discussions of what derogations are permissible. For Dworkin, for example, human dignity is an organising idea, as it brings ethical principles under the one roof of human dignity. ${ }^{22}$ The question of data protection is surely also connected to this matter.

The GDPR can be restricted with regard for example the transparency and information obligation as regards processing and controlling of data. Article 23 GDPR stipulates that Union or Member State law to which the data controller or processor is subject may restrict by way of a legislative measure the scope of the obligations and rights when such a restriction respects the essence of the fundamental rights and freedoms and is a necessary and proportionate measure in a democratic society to safeguard. These restrictions concern, inter alia, national security, defence or public security other important objectives of general public interest of the Union or of a Member State including monetary, budgetary and taxation a matters, public health and social security. The notion of what is necessary and proportionate action in a democratic society is of crucial importance here.

Moreover, recital 153 of the GDPR is interesting here and states that:

Member States law should reconcile the rules governing freedom of expression and information, including journalistic, academic, artistic and or literary expression with the right to the protection of personal data pursuant to this Regulation. The processing of personal data solely for journalistic purposes, or for the purposes of academic, artistic or literary expression should be subject to derogations or exemptions from certain provisions of this Regulation if necessary to reconcile the right to the protection of personal data with the right to freedom of expression and information, as enshrined in Article 11 of the Charter. This should apply in particular to the processing of personal data in the audiovisual field and in news archives and press libraries. Therefore, Member States should adopt legislative measures which lay down the exemptions and derogations necessary for the purpose of balancing those fundamental rights. Member States should adopt such exemptions and derogations on general principles, the rights of the data subject, the controller and the processor, the transfer of personal data to third countries or international organisations, the independent supervisory authorities, cooperation and consistency, and specific data-processing situations. Where such exemptions or derogations differ from one Member State to another, the law of the Member State to which the controller is subject should apply. In order to take account of the importance of the right to freedom of expression in every democratic society, it is necessary to interpret notions relating to that freedom, such as journalism, broadly.

Also, Article 83 of the GDPR stipulates that:

21 Schrems II (n 9).

22 Ronald Dworkin, Justice for Hedgehogs (Harvard University Press, 2011). 
For processing carried out for journalistic purposes or the purpose of academic artistic or literary expression, Member States shall provide for exemptions or derogations [...] if they are necessary to reconcile the right to the protection of personal data with the freedom of expression and information.

As we can see the derogations and restrictions in question are meant to maintain the highest possible standard in a Member States, not to lower the level of protection and any derogation has to be genuinely about the freedom of expression and information and it has to be proportionate. Presumably what is worth preserving is right to information about the state i.e. transparency rules and the standard of what is expected in and democracy in line with the rule of law. It is not about the horizontal dimension of a right to know everyone's private data and house address.

Related to this is the Commission's recent communication entitled 'Data protection as a pillar of citizens' empowerment and the EU's approach to the digital transition', charting the EU's progress on data protection the last two year. ${ }^{23}$ In this document the Commission stipulates that:

A specific challenge for national legislation is the reconciliation of the right to the protection of personal data with freedom of expression and information, and the proper balancing of these rights. ${ }^{24}$

In addition, the communication stresses that:

[Some] national legislations lay down the principle of precedence of freedom of expression, whilst others lay down the precedence of the protection of personal data and exempt the application of data protection rules only in specific situations, such as where a person with public status is concerned. Finally, other Member States provide for a certain balancing by the legislator and/or or a case-by-case assessment as regards derogations from certain provisions of the GDPR.

The Commission points out that:

Data protection rules (as well as their interpretation and application) should not affect the exercise of freedom of expression and information, for instance by creating a chilling effect or putting pressure on journalists to disclose their sources.

Moreover, the Commission argues that 'The reconciliation must be provided for by law, respect the essence of those fundamental rights, and be proportional and necessary (Article 52(1) of the Charter)'. Accordingly, the Swedish interpretation of the exceptions to the GDPR appears far too broad and there is no proportionality assessment at all. In other words, the exception as applied in Sweden, allows anyone who buys a license to be protected under freedom of expression and hereby to be granted an exception from the GDPR, without any proportionality assessment as to whether this contradicts the right to data protection. In other words, the classic balancing of rights is not done here. In practice the Swedish exception means that the data protection rules do not fully

${ }^{23}$ Communication from the Commission to the European Parliament and the Council "Data protection as a pillar of citizens' empowerment and the EU's approach to the digital transition - two years of application of the General Data Protection Regulation COM/2020/264 final.

24 ibid. 
apply in Sweden, as Swedish practices currently set aside EU data protection by allowing a very strange interpretation of the limits of freedom of expression. It is submitted that the Swedish derogation is not only disproportionate but that it goes against the whole idea of the GDPR and against loyalty, as it goes fundamentally against the protection personal data. ${ }^{25}$ So ironically while trying to preserve national constitutional law, the derogation is unconstitutional. It deprives citizens of their constitutional right to effective data protection and respect for their dignity as guaranteed both by the EU and the Swedish constitution, Ch 2 Regeringsformen (RF) as well as the ECHR. After all any derogation from the GDPR must respect the essence of the fundamental rights and freedoms, and be a necessary and proportionate measure in a democratic society to safeguard a public interest.

\section{THE PRINCIPLE OF PROPORTIONALITY}

The question of derogations under EU law are of course connected to the principle of proportionality, as already discussed above. It may be useful to look at proportionality a bit more closely. Common grounds for derogations from EU law, are of course national security, national identity, public security, health, public policy to name a few of them but they all have to pass the proportionality test to count as a valid justification. ${ }^{26}$

Article 52 EU Charter makes it clear that any permissible derogations by Member States from EU law obligations as set out in the Charter, are contingent on proportionality. In other words, proportionality is a doubled edged sword: the same principle of proportionality is protecting individual rights in a positive sense can also be used to limits those rights.

Yet in the Swedish case, any proportionality assessment doesn't seem to stand the proportionality test, and most importantly -and curiously - has not even been done. The exercise would be simple. When it concerns companies or individuals that apply for and buy a license but where press ethics and the special media laws (e.g. responsibilities for the editor in chief) or journalistic freedom matters are not at stake, there has to be a consent from the individual in question before any private information (such as home address, date of birth etc. etc.) about an individual is posted online. The question is not really about freedom of expression here but about obtaining information about private individuals from authorities that does not have any public interest (and is available for anyone who asks for it and visits the authority) and re-publish it online. Therefore, if there is no consent at least there has to be a proportionality assessment, and a balance between a 'right' to buy information and publish it and that of an individual's right to private life, dignity and data protection according to EU law.

The importance of the principle of proportionality as an EU constitutional principle is a well-known. The assumption is that interference with EU law rights should be kept to a minimum, in which the test is to ascertain whether it has been manifestly disproportionate to interfere with these rights. The principle of proportionality is a multifaceted principle, both a legislative principle and a free movement principle. Furthermore, it is a general EU law principle of great constitutional importance. Clearly, the principle of proportionality can be viewed as pointing in the same direction as reasonableness. The CJEU will inquire as to

\footnotetext{
${ }^{25}$ For a recent analysis of derogations and the GDPR, see eg. Jef Ausloos, The Right to Erasure in EU data protection law (Oxford University Press 2020).

26 Stephen Weatherill, Law and values in the European Union, (Oxford University Press 2016), ch 4.
} 
whether the measure was suitable or appropriate to achieve the desired result or whether this could have been attained by a less onerous method. Proportionality is therefore a general review in EU law that is applicable to test the legality both of EU action, and of Member State action when the latter falls within the ambit of the Treaty. ${ }^{27}$ Moreover, the individual plays an increasingly important role in the EU context. For example, Article 3 TFEU makes it clear that not only is the Union to aim to promote the well-being of its peoples, but it is also to offer its citizens an area of freedom, security and justice without internal frontiers, in which the free movement of persons is ensured. This implies a balance not only vis-à-vis the EU and its Member States, but also between the individual and the EU. ${ }^{28}$ The CJEU will inquire as to whether the measure was suitable or appropriate to achieve the desired result or whether this could have been attained by a less onerous method. The relationship between the EU and the Member States is often described in terms of balancing: the EU only has the powers allocated to it by the Member States. Nonetheless, pinning down these boundaries set by the proportionality principle is sometimes challenging, where proportionality has also formed the leitmotiv in European law in a more general sense. After all, it is also a general principle of EU law that has to be taken into account in all actions of EU law, such as the creation and management of the internal market, as well as the operation of the Treaty freedoms.

Furthermore, the Member States could invoke proportionality to derogate from the rights guaranteed in the Charter since Article 52 applies to all rights. The explanatory memorandum on the Charter confirms that these exceptions are based upon the Court's well-established case law, which shows that restrictions may be imposed on the exercise of fundamental rights. The explanatory notes also make it clear that the reference to the general interests recognised by the Union covers both the objectives mentioned in Article 3 TFEU and other interests protected by specific provisions of the Treaties provided that those restrictions do, in fact, correspond to objectives of general interest of the EU. Moreover, these explanatory notes state that such restrictions may not, with regard to the aim pursued, be disproportionate or cause unreasonable interference which would undermine the very substance of any Charter rights. ${ }^{29}$

There is also an external dimension. In several recent cases such as Digital Rights and Schrems 1 \& 2, the CJEU has stressed the EU's data protection rules cannot be derogated from without any justification. The proportionality review and the need to secure equivalent protection of data protection in cooperation with third states is interesting in the Swedish case. When data is published online it also become a global question as the data is available to third countries also. From this perspective it could be argued that actually EU data protection rules are not complied with when it comes to the importance of upholding EU standards with regard to third states. Therefore, it could be questioned whether data protection in the EU is not lived up with vis-à-vis third countries.

\footnotetext{
${ }^{27}$ Paul Craig EU Administrative Law (Oxford University Press 2012).

${ }^{28}$ Craig ibid chs 19-20, for an extensive overview of the notion of proportionality in EU law, Stephen

Weatherill, Law and V alues in the European Union (Oxford University Press, 2016).

${ }^{29}$ The Explanations relating to the Charter of Fundamental Rights, [2007] OJ C83/2.
} 


\section{HINDERING MARKET ACCESS?}

Now the final issue I would like to briefly address is that of the familiar internal market dimension and that of market access. If only private data regarding private life, earnings, status etc. are available online for those registered and living in Sweden, it could be argued that it puts Swedes at a disadvantage when using their free movement right to conduct business. Another interesting aspect here is the link between the commerce in personal data has become the subject of trade and where undertakings compete to obtain and process this data. It has been suggested that this rivalry falls within the sphere of competition law. ${ }^{30}$ In other words, the Swedish system may face more challenges than that of data protection.

\section{CONCLUSION - THE SWEDISH SYSTEM NEEDS TO CHANGE}

The right to data protection should not be set aside because of a disproportionate reading of the GDPR and the derogations, as the Swedish derogation at this moment is contrary to the idea of the Regulation. Besides, this is secondary legislation and the rights to data protection, dignity and privacy are Treaty based primary rights. There should be a uniform application of EU data protection rules in the EU so that all EU citizens are guaranteed the same level of protection. Moreover, there needs to be a proportionality assessment of the Swedish derogation as well as an examination of the true justification, i.e. if the state wants to earn money from selling the information or whether it is really about freedom of expression. In any event as is well known from both EU and ECHR case law, if there is a conflict of rights, there needs to be balance between those rights. It seems utterly wrong that if you are a publisher you have many constraints regarding what you can publish and you have to observe press ethics, but if you buy a license you can do what you want and breach EU data protection laws while the state earns money from it. The Commission ought to bring an infringement procedure against Sweden for breach of EU data protection rules.

\footnotetext{
30 Xavier Groussot \& Anna Zemskova 'The I-Rule of Law in the Making: a Constitutional Perspective on the GDPR', 2020 Sep 12, 8 p. EU Law Live. See also Orla Lynskey, The Foundations of EU Data Protection Law (Oxford University Press 2015).
} 


\section{LIST OF REFERENCES}

M Avbejil and J Komarek (eds) Constitutional Pluralism in the European Union and Beyond (Hart publishing 2012).

DOI: https://doi.org/10.5040/9781472561121

$\mathrm{J}$ Ausloos, The Right to Erasure in EU data protection law (Oxford University Press 2020).

DOI: https://doi.org/10.1093/oso/9780198847977.001.0001

U Bernitz, S De Vries, X Groussot, J Paju (eds) General Principles of EU Law and the EU Digital Order (Kluwer law 2020).

P Craig, EU Administrative Law (Oxford University Press 2012)

DOI: https://doi.org/10.1093/acprof:oso/9780199296811.001.0001

R Dworkin, Justice for Hedgehogs (Cambridge MA, Harvard University Press, 2011).

DOI: https://doi.org/10.2307/i.ctvif9vkt

X Groussot \& A Zemskova "The I-Rule of Law in the Making: a Constitutional Perspective on the GDPR”, 2020 Sep 12, 8 p. EU Law Live. https://issuu.com/eulawlive/docs/we 28

E Herlin-Karnell, The Constitutional Structure of Europe's Area of Freedom, Security and Justice (Hart publishing 2019)

M Kumm, 'Beyond Golf Clubs and the Judicialization of Politics: Why Europe Has a Constitution Properly So Called' (2006) 54 American Journal of Comparative Law, 505

DOI: https://doi.org/10.1093/ajcl/54.suppl1.505

O Lynskey, The Foundations of EU Data Protection Law (Oxford University Press 2015)

L Pech and K Lane Scheppele "Illiberalism Within: Rule of Law Backsliding in the EU" (2017), 19 Cambridge Yearbook of European Legal Studies 3-47

DOI: https://doi.org/10.1017/cel.2017.9

A von Bogdandy and J Bast (eds) Principles of European Constitutional Law (Oxford/Munich, Hart/Beck, Nomos, 2009)

S Weatherill, Law and Values in the European Union (Oxford, Oxford University Press, 2016) DOI:

K Zeigler, V Moreno-Lax and P Neuvonen (eds), Handbook on EU General Principles, (Edward Elgar 2021) forthcoming 